\title{
UNA MICRO-ECONOMÍA EN LA FRONTERA SUR DEL REINO DE CHILE EL COLEGIO DE MISIONES DE CHILLÁN HACIA FINES DE LA COLONIA*
}

\author{
Cristián Leal Pino** \\ Universidad el Bío-Bío (Chile)
}

El artículo analiza la dinámica económica del Colegio de misiones de Chillán en la frontera sur del Reino de Chile hacia fines de la Colonia. Identifica los recursos económicos con que contaba el Colegio para llevar a cabo su labor misionera en tierra de fieles y gentiles, como también las vinculaciones económicas que generó con los hacendados, comerciantes, misiones y población pehuenche.

Por medio de los libros de Cuentas, Disposiciones, Informes, Cartas, hemos podido determinar que el Colegio de misiones de Chillán logró establecer una red económica que tuvo como base el sínodo asignado por la Corona, sus propiedades y bienes semoventes, lo que permitió no sólo la subsistencia de los frailes, sino que también contribuyó a generar espacios de sociabilidad en la frontera sur del imperio español.

Palabras claves: Reino de Chile- Franciscanos- Colegio de misiones- Chillán- micro-economía

\section{A MICRO-ECONOMY ON THE SOUTHERN BORDER OF THE KINGDOM OF CHILE: THE COLLEGE OF MISSIONS OF CHILLÁN TOWARDS THE END OF THE COLONY}

The article analyzes the economic dynamics of the College of Missions of Chillán on the southern border of the Kingdom of Chile towards the end of the Colony. It identifies the economic resources available to the College to carry out its missionary work in the land of the faithful and Gentiles, as well as the economic links it generated with local landowners, merchants, missions and the pehuenche population.

Through the books of Accounts, Provisions and Statutes, we have been able to determine that the College of Missions of Chillán, managed to establish an economic network based on the synod assigned by the Crown, its properties and moving assets, which allowed not only the subsistence of the friars, but also contributed to generate spaces of sociability on the southern border of the Spanish empire.

Keywords: Kingdom of Chile- Franciscans- College of Missions- Chillán-microeconomics

Artículo Recibido: 15 de Enero de 2018

Artículo Aceptado: 10 de Marzo de 2018

\footnotetext{
* Este artículo es resultado de la investigación realizada en el marco del Proyecto Fondecyt iniciación $\mathrm{N}^{\circ}$ 11160795, denominado: Vida conventual y formas de financiamiento en una Orden mendicante en Chile: Los franciscanos en el tránsito de la Colonia a la República.

**E-mail:cleal@ubiobio.cl
} 


\section{Introducción}

T a administración de los bienes temporales de los religiosos franciscanos estaba claramente establecida en sus Estatutos Generales ${ }^{1}$. Los bienes recibidos por donaciones de sus feligreses debían ser administrados por un laico, que controlaba los gastos e ingresos bajo la supervisión y consejo de los padres discretos ${ }^{2}$. Los Colegios de misiones recibían un sínodo anual para desarrollar su labor en tierra de fieles y gentiles, el cual por lo general llegaba a destiempo, generando así una gran dependencia de las limosnas que debían suplir dichos inconvenientes.

En la práctica, y ante las necesidades crecientes de su labor evangelizadora y civilizadora, no siempre se cumplió con lo establecido en su Regla y en los Estatutos en materia económica. Gabriel Guarda nos dice que: «Las rentas producidas por la mala explotación del patrimonio territorial, ni los intereses de los censos, capellanías y limosnas, alcanzaban para sostener la economía de las comunidades, por lo que debían recurrir a bienes particulares, contrarios a la pobreza y a su calidad de mendicante», es más, y aquí está lo interesante, visualiza que las órdenes, como la franciscana, incursionaron en «actividades lucrativas reñidas con las reglas de sus institutos» ${ }^{3}$.

\footnotetext{
1 Estatutos Generales de Barcelona para la familia cismontana de la Regular observancia de N.P.S. Francisco, Madrid, 1746, p. 18.

${ }^{2}$ Revuelta, Manuel, La exclaustración (1833-1840), Editorial Católica, Madrid, 1976, p. 29.

3 Guarda, Gabriel, La Edad Media de Chile. Historia de la Iglesia desde la fundación de Santiago a la incorporación de Chiloé, 1541-1826, Colección Arte y Cultura, Ediciones UC, Santiago, 2016, p. 483.
} 
Los Colegios de misiones «eran entidades autónomas, con estatutos propios y cuyo fin principal eran las misiones entre los infieles en un territorio determinado» ${ }^{4}$. De igual forma, debían brindar estabilidad y continuidad a las misiones, ser centros de instrucción de los misioneros y lugar de renovación física y espiritual de los religiosos.

El análisis sobre el tema económico en los conventos, al menos para la realidad mexicana, argentina y peruana no es nuevo. Los trabajos señeros en esta línea han sido los de Asunción Lavrin ${ }^{5}$ y Gisela von Wobeser ${ }^{6}$ para el caso mexicano. La primera, en sus estudios sobre los conventos de monjas y las cofradías novohispanas, nos habla de la «economía espiritual» y la «economía material», donde precisa que las instituciones religiosas, tales como las parroquias, órdenes religiosas, cofradías, giran en torno a una doble hélice, «sus fines éticos o espirituales y los medios materiales de que depende su existencia» ${ }^{7}$.

Siguiendo la línea de los conventos de monja, oportuno es señalar los aportes sobre la realidad peruana, que enfatizan el rol espiritual y económico de estos institutos. Kathryn Burns ${ }^{8}$ centra su investigación en los conventos cuzqueños y sus conexiones con la sociedad colonial denominándola «economía espiritual», mientras que Nancy van Deusen ${ }^{9}$, analiza las instituciones de religiosas en Lima y el aumento del número de mujeres seglares conviviendo con ellas.

Gisela von Wobeser, quien amplía su análisis hacia los conventos masculinos, junto con analizar el crédito eclesiástico y las capellanías en tiempos de Carlos III y IV, se enfoca en el tema de la consolidación de los vales reales en diócesis, parroquias y conventos. La finalidad de la política real era superar el déficit económico ocasionado por las sucesivas guerras europeas. El listado de conventos afectados, incluyendo el franciscano, es muestra de lo que significó el poder de los reyes borbónicos en el contexto de la Nueva España ${ }^{10}$.

Para el caso argentino encontramos interesantes avances en materia económica. Los

\footnotetext{
${ }^{4}$ Etcheverry, Paulinna, Las Prefecturas Franciscanas de Misiones en Chile, Publicaciones del Archivo Franciscano (en adelante PAFSCh.), Santiago, $N^{\circ}$ 71, 2002.

${ }^{5}$ Lavrin, Asunción, «Cofradías novohispanas: economías material y espiritual», en Cofradías, capellanías y obras pías en la América colonial, María Martínez, Gisela y von Wobeser, Juan Muñoz (coordinadores), Serie Historia Novohispana, 61, Universidad Nacional Autónoma de México, 1998 (pp. 49-64).

${ }^{6}$ Von Wobeser, Gisela, El Crédito Eclesiástico en la Nueva España, siglo XVIII, Universidad Autónoma de México, México, 1994; Dominación Colonial. La consolidación de vales reales, 1804-1812, Instituto de Investigación Histórica, Universidad Nacional Autónoma de México D.F, México, 2003.

${ }^{7}$ Lavrin, Asunción, op. cit., p. 49.

${ }^{8}$ Burns, Kathryn, Colonial Habits: Convents and the Spiritual Economy of Cuzco, Peru. Duke University Press, EEUU, 1991.

9 Van Deusen, Nancy, «Instituciones religiosas en el mundo colonial americano», en Manifestaciones religiosas en el mundo colonial americano, de Garcia, C. y Ramos, M. (cord.), Universidad Iberoamericana, México, 1994 (pp. 65-86).

${ }^{10}$ Von Wobeser, Gisela, Dominación Colonial..., op. cit.; Vida eterna y preocupaciones terrenales. Las capellanías de misas en la Nueva España, 1700-1821, UNAM, México, 1999; El Crédito Eclesiástico en..., op. cit.
} 
historiadores han podido constatar que los conventos y monasterios necesitaban asegurar la subsistencia de sus comunidades y posibilitar el ingreso de otros, así como también financiar sus diversas actividades, de modo que los frailes y monjas llevaban adelante una política de inversiones que buscaban garantizar la conservación y reproducción de sus bienes. En este sentido, Roberto Di Stefano y Loris Zanatta ${ }^{11}$, se preguntaban por el dinero que prestaban los conventos (catalogados como los bancos de América), los bienes capellánicos (fuente de grandes recursos para la época), y quiénes se vinculaban económicamente con los conventos, donde aparecían los hacendados, comerciantes, militares, entre otros ${ }^{12}$.

Dichos autores señalaban que colocar un hijo en el clero regular también tenía alguna ventaja, como lo era «el estrechamiento de los lazos entre el convento y la familia que le había donado un hijo, lo que podía redundar potencialmente en accesos a préstamos desgajados del patrimonio de la comunidad, alimentado incesantemente por las donaciones de otras familias» ${ }^{13}$. En definitiva, concibe al convento como una entidad que concentra y asigna recursos a los distintos clanes, a los que prefiere a la hora de vincularse económicamente, asegurando con ello la «reproducción de la comunidad, la celebración del culto, el despliegue de actividades pastorales y misioneras. Un patrimonio espiritualizado, pero no por ello menos palpable y concreto» ${ }^{14}$.

En esta línea, historiadores como Carlos Mayo y Jaime Peire han llegado a la conclusión que «los préstamos constituían una inyección muy importante de dinero en la economía colonial y que la lógica que movía las decisiones de los frailes era enteramente racional y económica, si bien tenía como objetivo último no la acumulación en sí, sino el financiamiento de sus actividades» ${ }^{15}$. En este sentido y siguiendo a Roberto Di Stefano y Loris Zanatta «estaríamos muy lejos de una Iglesia que inmoviliza el dinero que le donan sus fieles» ${ }^{16}$. El clero regular porteño tenía ingresos por los establecimientos productivos que tenía en la ciudad y en el campo, así como por el alquiler de fincas y casas. En cuanto a los préstamos, la lógica fue optar por inversiones seguras, aunque fuesen menos redituales, haciéndose común arrendar en vez de una explotación directa de las propiedades ${ }^{17}$.

En el libro El Taller de los Espejos, Iglesia e imaginario en 1767 1815, es posible

\footnotetext{
${ }^{11}$ Di Stefano, Roberto, Zanatta, Loris, Historia de la Iglesia Argentina, Editorial Sudamericana, Buenos Aires, 2009; Di Stefano, Roberto, El púlpito y la plaza. Clero, sociedad y política de la monarquía católica a la república rosista, Siglo XXI editores, Buenos Aires, 2004.

${ }^{12}$ Di Stefano Roberto, Zanatta, Loris, Historia de la Iglesia Argentina..., op. cit., p. 72-77.

${ }^{13}$ Di Stefano, Roberto, El púlpito y la plaza..., op. cit., p. 59.

${ }_{14}$ Ídem.

${ }^{15}$ Mayo, Carlos, Peire, Jaime, «Iglesia y crédito colonial: La política crediticia de los conventos de Buenos Aires (1767-1810)», Revista de Historia de América, № 12, 1991 (pp.147-157), p. 75.

${ }^{16}$ Di Stefano, Roberto, Zanatta, Loris, La Iglesia en Argentina..., op. cit., p. 75.

17 Ídem.
} 
observar la importancia de las órdenes religiosas en el sistema crediticio, más aún en una economía donde el capital estaba ligado a la tierra y el comercio, sin bancos y necesitados de créditos $^{18}$. La necesidad de circulante generó que alrededor de los conventos existiera una elite de hacendados, comerciantes y militares que hicieran todo lo posible por tener acceso al crédito, y recurriendo a diversos mecanismos para lograrlo, incluso teniendo indirectamente participación en los capítulos provinciales donde se elegían las principales autoridades eclesiásticas ${ }^{19}$. Dependiendo de quienes fueran elegidas, también dependía el acceso al crédito. No menor, en esta relación económica entre los conventos y la sociedad, fue la participación de las mujeres, quienes mayormente solicitaban censos, «desmintiendo la pretendida inactividad de la mujer colonial» ${ }^{20}$.

El caso chileno es un tanto distinto, ya que son pocos los trabajos que se dedican a analizar el tema, existiendo más bien generalizaciones que certezas. Gabriel Guarda señala que el problema está en que «no existen fuentes sistematizadas que permitan extraer una conclusión general respecto a cada a una de las órdenes» ${ }^{21}$, de ahí que tengamos imágenes incompletas de dicha realidad y aseveraciones poco afortunadas respecto a la riqueza de las mismas. Por otro lado, entre quienes se han dedicado al tema económico de las órdenes religiosas, nos brindan imágenes dicotómicas de las mismas, por un lado nos hablan de la riqueza de éstas, y por otra, nos señalan que los conventos fueron «pobres y ruinosos».

Por su parte René Millar y Carmen Duhart ${ }^{22}$ citando un Informe de la Real Audiencia de mediados del siglo XVIII, señalaban que la Compañía de Jesús era la única Orden que «mantenía en forma digna a sus clérigos, al contrario de lo sucedido con las demás órdenes por sus cortos fondos, y por su poca aplicación al manejo y cultivo de sus haciendas» ${ }^{23}$.

¿Qué nos dice la historiografía sobre el Colegio de misiones de Chillán en materia económica? No es mucho lo que sabemos. Por ejemplo, quienes en los últimos años han investigado sobre dicho Colegio, su interés ha estado lejos del ámbito económico. Por ejemplo, algunos han puesto el énfasis en el rol político de los frailes, ya sea como

\footnotetext{
18 Peire, Jaime, El Taller de los Espejos. Iglesia e imaginarios 1767-1815, Editorial Claridad, Buenos Aires, 2000.

19 Ídem.

20 Ibídem, p. 132.

${ }^{21}$ Guarda, Gabriel, op. cit., p. 483.

${ }^{22}$ Millar, René, Duhart, Carmen, «La vida en los claustros: Monjas y frailes, disciplinas y devociones», en Historia de la vida privada en Chile. El Chile tradicional de la conquista a 1840, Editorial Taurus, Santiago, 2007 (pp. 125-159).

23 Ibídem, p. 144.
} 
mediadores en la frontera araucana ${ }^{24}$ o en tiempos de la Independencia de Chile ${ }^{25}$; otros, han focalizado sus investigaciones en el rol evangelizador y civilizador que cumplieron los misioneros en tierras araucanas durante el siglo XVIII26, abandonando decididamente el aspecto económico.

En este sentido, ¿Qué ocurría en el Reino de Chile en materia económica? y ¿en qué condiciones materiales funcionaba el Colegio de misiones de Chillán? Durante el siglo XVIII el comercio en la política de la Corona española emergió como un sector gravitante ${ }^{27}$, y se desarrolló «de acuerdo a las directrices borbónicas de mayor centralización y control administrativo de las colonias americanas» 28 . Un ejemplo de las transformaciones de la economía del siglo XVIII en el Reino de Chile, fue el interés del cabildo de Concepción de «promover la venta de instrumentos agrícolas de hierro a los agricultores mapuche, especialmente arados y azadones, con el objeto de incrementar el cultivo de trigo $[\ldots] »^{29}$.

En la zona de frontera existió un «notable y bastante regular comercio fronterizo que se podría sintetizar en la exportación de ponchos y otros tejidos, y la importación de añil y otros colorantes» ${ }^{30}$, sin embargo no es propio hablar de «mercados indígenas o mestizos con especificación de su funcionamiento» ya que «hubo mucho más un mercado colonial agrícola que correspondía a una extensa y complicada red de tejidos entrelazados entre productores y vendedores» ${ }^{31}$.

En consecuencia, asumimos nuestra investigación desde una perspectiva socioeconómica, con el objeto de determinar las condiciones materiales en que vivían los frailes del Colegio de Propaganda Fide de San Ildefonso de Chillán hacia fines de la Colonia, en vísperas de las luchas por la independencia. El estudio es de carácter mixto (cualitativo cuantitativo), donde las principales fuentes de información fueron los libros de cuentas, disposiciones, estatutos, cartas e informes, con las cuales nos aproximamos a la realidad socioeconómica del Colegio. La información se organizó en categorías de análisis, que permitieron la elaboración de tablas, gráficos y mapas, lo que

\footnotetext{
${ }^{24}$ Viñuela, Rebeca, «Los Franciscanos del Colegio de Propaganda FIDE de San Ildefonso de Chillán como mediadores políticos en la Frontera Araucana del siglo XVIII", en América Cruces de Miradas, de Cañedo y Argüelles, Teresa (coord.), 2 volúmenes, Universidad de Alcalá, España, 2015 (pp. 577-602). ${ }^{25}$ Valenzuela, Jaime, «Los Franciscanos de Chillán y la Independencia: Avatares de una comunidad monarquista», Revista Historia, №38, Vol. I, enero-junio, Santiago, 2005 (pp. 113-158).

${ }^{26}$ Leal, Cristián, Quitral Andrés, «Evangelización y occidentalización en la frontera sur del Reino de Chile. Los Franciscanos del Colegio de Misiones de Chillán, s. XVIII», en Revista Historia y MEMORIA, № 15, Julio-Diciembre, Tunja, 2017 (pp.139-168).

${ }_{27}$ Cavieres Figueroa, Eduardo, Servir al soberano sin detrimento del vasallo. El comercio hispano colonial y el sector mercantil de Santiago de Chile en el siglo XVIII, Valparaíso, 2003, p. 209.

${ }_{28}$ Pinto Rodríguez, Jorge e Inostroza Córdova, Iván, Expansión capitalista y economía mapuche: 16801930, Ediciones Universidad de La Frontera, Temuco, 2014, p. 45.

29 Ibídem., p. 46.

${ }^{30}$ Cavieres Figueroa, Eduardo. Sobre la Independencia en Chile. El fin del Antiguo Régimen y los orígenes de la representación moderna, Ediciones Universitarias de Valparaíso, Valparaíso, 2012, p. 184.

31 Ídem.
} 
posibilitó describir la realidad material de los frailes y establecer sus vinculaciones económicas con la población hispano criolla y aborigen en una zona de frontera.

\section{Chillán y su economía hacia el siglo XVIII}

En los inicios del siglo XVIII Chillán era una ciudad con un gran potencial agropecuario que se vinculaba no sólo con mercados locales, sino que también con las grandes ciudades del Reino y el Perú. El gobernador Marín de Poveda, en carta al Rey, con fecha 28 de abril de 1700, describía la «región chillaneja» como una «tierra llana, fértil y abundante de todos cuantos frutos produce el Reino de pan, carnes, vino, frutas y legumbres de propia tierra y de Castilla, y de muchos pastos para la crianza de ganados mayores y menores de todas las especies» ${ }^{32}$. Además, agregaba la existencia de productos tales como el sebo, cordobanes, mulas, cabras y ovejas con destino a Perú, Santiago, Concepción y los partidos que la circundaban ${ }^{33}$.

Décadas más tarde, en el año 1760, el presidente Amat y Junient, informaba a Carlos III de las bondades de este territorio, dando una visión positiva de Chillán. Por ejemplo, señalaba que se «trasquila muy buena lana y en abundancia, de manera que es uno de los mejores renglones de su comercio el trabajo de la mujeres en telas, que tejen en los telares ordinarios» ${ }^{34}$, luego agregaba que el trigo «se cosechaba en abundancia» y que los cordobanes y suelas, eran «de buena reputación» 35 .

La demanda peruana generó en la «región chillaneja» una reorganización de la estructura agraria productiva, que en los siglos anteriores había estado dedicada a la ganadería. Ahora, y gracias al mercado peruano, «devinieron en importantes proveedores de trigos y vinos» ${ }^{36}$. La llamada «fiebre del trigo», tuvo también repercusiones en las haciendas locales al punto de generar más de alguna alteración en el mercado interno regional.

La actividad adquirió un dinamismo que generó un fenómeno migratorio, al punto que en Chillán y la provincia de Rere, las tareas agrícolas se hacían con peones alquilados ${ }^{37}$. El propio Concepción era visto con un gran potencial agrícola, con

\footnotetext{
32 Casanova Guarda, Holdenis. Diablos, Brujos y Espíritus Maléficos. Chillán, un proceso judicial del siglo XVIII, Ediciones Universidad de La Frontera, Temuco, 1994, p. 32.

33 Ídem.

34 «Informe del Presidente Amat y Junient a Carlos III, 1760» en Domingo Amunátegui Solar, Hijos llustres de Chillán, Prensa de la Universidad de Chile, Santiago, 1937, p. 55.

35 Ídem.

${ }^{36}$ Casanova Guarda, Holdenis, Diablos, Brujos y Espiritus Maléficos... op. cit., p. 32.

${ }^{37}$ León Solís, Leonardo. Maloqueros y conchavadores en Araucanía y las pampas, 1700-1800, Universidad de la Frontera, Temuco, 1990, pp. 127-131.
} 
abundancia de agua y buenas tierras que en las «postrimerías del siglo XVIII mostraba claras señales de crecimiento. Hubo un incremento de la producción triguera y de las exportaciones agropecuarias; el aumento de la población favoreció la formación de un mercado interno y las relaciones fronterizas se estabilizaron, permitiendo el desarrollo de un comercio en beneficio mutuo entre hispano criollos e indígenas» ${ }^{38}$.

La economía en el espacio fronterizo generó importantes circuitos comerciales donde se desarrollaron a lo menos tres ámbitos de intercambio: «a nivel local que ocurrió alrededor de las comunidades indígenas y las haciendas fronterizas, otro que involucró a la Araucanía y a las Pampas y un tercero que conectó a toda la Frontera con el resto del Imperio» 39 .

El tráfico fronterizo se vinculó desde temprano a los españoles y araucanos (también a los pehuenches) en un intercambio que se fue desarrollando progresivamente a medida que aumentaban las condiciones pacíficas y las necesidades de los grupos. Sirvieron de apoyo a este comercio, las ciudades de Concepción, Chillán, Los Ángeles, las plazas y fuertes de la frontera, las misiones y las estancias próximas al Biobío40.

El intercambio local es el que nos interesa, que era el más intenso y complejo, y que se desarrollaba en las propias parcialidades indígenas, los fuertes, haciendas y estancias fronterizas. El visitador Juan Ojeda en 1793 señalaba que en dicho espacio, «el comercio activo de los pehuenches con los españoles consistía en sal, ponchos, plumajes, bateas, canastos, pellejos, añil, alaborios y algunas mercerías» ${ }^{41}$.

Con el tiempo fueron apareciendo nuevas necesidades que cambiaron la vida de los pehuenches. Además del caballo y su carne, «el trigo, el vino, el aguardiente y los objetos de hierro se hicieron indispensables y determinaron el acercamiento a los invasores que, a su vez, requerían de sal, los ponchos y los caballos» ${ }^{42}$. Temían los pehuenches a los ataques de los huilliches y araucanos, y por ello buscaron protección en las fuerzas hispano criollas a través del comercio.

El desarrollo económico de Chillán «quedó íntimamente ligado a las actividades agropecuarias, centradas en las estancias y haciendas de sus alrededores», cuya expansión fue «estimulada por las crecientes exportaciones de trigo al Perú», lo que en definitiva se constituyó en «importantes focos de atracción laboral para un conjunto heterogéneo de trabajadores libres -españoles pobres, negros indígenas y mezclas

\footnotetext{
${ }^{38}$ Cartes Montory, Armando (Editor), El regreso del Prócer Don Juan Martínez de Rozas en la ciudad de Concepción, Ediciones del Archivo Histórico de Concepción, Concepción, 2017, p. 31-32.

39 Ibídem., p. 32.

40 Casanova Guarda, Holdenis, Las rebeliones araucanas del siglo XVIII, Ediciones Universidad de La Frontera, Serie Quinto Centenario, Temuco, 1987.

${ }^{41}$ Cartes Montory, Armando (Editor). El regreso del Prócer... op. cit., p. 33.

42 Villalobos Rivera, Sergio. Los pehuenches en la vida fronteriza, Ediciones Universidad Católica de Chile, Santiago, 1989, p. 12.
} 
estables o temporales, en calidad de inquilinos o peones, retenidos mediante diversas modalidades salariales y distintos tipos de participación o usufructo» ${ }^{43}$.

En este contexto de oportunidades económicas, de circuitos comerciales, de relaciones económicas entre los españoles, criollos y población indígena, ¿qué ocurría en el Colegio de Misiones de Chillán en cuanto al sustento económico que necesitaban para llevar a cabo su labor evangelizadora? Puntualmente nos preguntamos si efectivamente la prosperidad económica externa al Colegio es posible observarla al interior de éste, con qué propiedades contaba, cuáles eran sus ingresos económicos a parte del sínodo, con quiénes logró establecer relaciones económicas. Son las preguntas que pretendemos responder en las siguientes páginas.

\section{El Colegio de Misiones de Chillán en el siglo XVIII: Una micro-economía en la frontera del Reino de Chile ${ }^{44}$.}

El convento de los frailes seráficos habría sido fundado prácticamente con la ciudad de Chillán en el año $1580^{45}$. Hacia 1584, los religiosos contaban con un solar, a partir del cual se fue construyendo paulatinamente dicho instituto para brindar atención espiritual a los españoles. En los siguientes siglos coloniales, esta labor se desplegará, al igual que los jesuitas, hacia tierra de infieles ${ }^{46}$.

En el año 1756, el convento se trasforma en Colegio de misiones de Propaganda Fide de San Ildefonso de Chillán, con el objeto de reimpulsar el fervor misionero de los franciscanos, que tantos frutos había dado en los siglos anteriores ${ }^{47}$. Durante la segunda mitad del siglo XVIII albergó a un número importante de frailes, siendo el año 1770 de 40 entre religiosos y legos. Hacia el año 1790, el total era de 78, siendo 60 religiosos y 18 legos, los que se distribuían de la siguiente manera: 50 en el Colegio, 25 en las misiones 25 y 3 en el seminario de Naturales ${ }^{48}$.

Los inicios del Colegio de misioneros no fueron nada de fáciles. Los escritos de Roberto $\operatorname{Lagos}^{49}$ y Gabriel Guarda ${ }^{50}$ nos brindan una imagen ruinosa de dicho instituto. En este sentido, no debemos olvidar la serie de sismos acaecidos durante el siglo XVIII, particularmente los ocurridos en los años 1730 y 1751, los cuales generaron una

\footnotetext{
43 Casanova Guarda, Holdenis. Diablos, Brujos..., op. cit., p. 37.

44 Un avance sobre este apartado lo encontramos en Leal, Cristián, «La realidad económica del Colegio de Propaganda Fide de Chillán en el periodo tardo colonial», en Cáceres, Juan, Tobar, Leopoldo y Leal, Cristián (editores), Lecturas y (RE) Lecturas en Historia Colonial II, Andros impresores, Santiago, 2013 (pp. 215-237).

45 Olivares, Luis, Provincia Franciscana de Chile, Universidad Católica, Santiago, 1961, p. 98.

46 Gutiérrez, Bernardino, Catalogo de las casas de la Provincia Franciscana de la Santísima Trinidad (1553-1890), PAFSCh, Nº 33, 1994, p. 15

47 Guarda, Gabriel, op. cit., p. 191.

48 Lagos, Roberto, Historia de las misiones del Colegio de Chillán, Ediciones Herederos Juan Gil, Barcelona, España, 1908.

49 Ídem.

${ }^{50}$ Guarda, Gabriel, op. cit.
} 
destrucción considerable en la ciudad de Chillán. En carta de Agustín de Soto y Aguilar al gobernador Domingo Ortiz de Rozas, con fecha 29 de mayo de 1751, señalaba:

Entre las ruinas con notable diligencia he conseguido este pliego de papel para participar a vuestra excelencia la ruina tan horrible que ha padecido esta ciudad el dia 24 a media noche con los temblores tan horrible y tan repetidos que no ha quedado templo ninguno ni menos casa alguna porque todas están totalmente por los suelos y dudábamos de tan fuertes sacudimientos si la tierra nos tragaba o si los edificios que caían nos aplastaban... ${ }^{51}$.

Sin embargo, hacia fines del siglo XVIII el Colegio había superado los embates de los terremotos y se perfilaba como un instituto estable y con capacidad para albergar un número creciente de religiosos. Los testimonios de los frailes seráficos dan cuenta de lo señalado. Por ejemplo, Miguel de Ascasubi, indicaba hacia el año 1789 que el Colegio contaba con una iglesia de sesenta varas de largo, de piedra tosca labrada y alhajada con la decencia que permite nuestro Instituto y la pobreza del país, con viviendas y oficinas adecuadas para una comunidad de sesenta religiosos, que subsistían con la limosna de la piedad de los fieles ${ }^{52}$. Además, hacía ver la abundancia que tenían en el ámbito de lo comestible, señalando:

El terreno es el más ventajoso que puede desearse, así para la subsistencia de los religiosos por lo favorable de su tiempo y por lo abundante de toda suerte de carnes, granos, frutas y hortalizas..., como también y más principalmente para los varios ramos y ejercicios del ministerio apostólico ${ }^{53}$.

Los Colegios de misiones contaban con el financiamiento de la Corona a través de la asignación de un sínodo, sin embargo, estos de igual modo recibían limosnas de los feligreses, de carácter gratuita y onerosa, que administraban con racionalidad y rigurosidad. Hacia fines del siglo XVIII, el Colegio contaba con recursos económicos importantes que le permitieron enfrentar los últimos años de la Colonia de manera satisfactoria. Entre sus propiedades destacaban el fundo Los Guindos y los predios de El Castillo y La Esperanza ${ }^{54}$. El primero de ellos, de 672 cuadras, localizado a 10 kilómetros al oriente de la ciudad de Chillán, era el más importante, no sólo por su ubicación, sino que también por la producción en alimentos que genera para los frailes.

Los otros fundos, localizados en sector precordillerano, de poco valor en cuanto a su productividad, pero de gran importancia para proveer de leña y madera, tema no

\footnotetext{
51 Palacios, Alfredo, Fuentes para la historia sísmica de Chile (1570-1906). Fuentes para la Historia de la República, volumen XLI. Dirección de Bibliotecas, Archivos y Museos, Santiago, 2016, p. 149.

${ }^{52}$ Ascasubi, Miguel, Informe cronológico de las misiones del Reino de Chile hasta 1789, en, PAFSCh., $\mathrm{N}^{\circ}$ 49, 1997.

53 Ibídem., p. 8.

54 Iturriaga, Rigoberto, Secuestro de Bienes, 1824, PAFSCh., N 40, 1995.
} 
menor en la reparación y construcción de edificios tanto del Colegio como de las misiones en tierras de Arauco y Valdivia. El predio La Esperanza, con 448 cuadras $^{55}$ y El Castillo con 1.000, que junto al de Los Guindos sumaban la cantidad de 2.122 cuadras.

Es oportuno señalar, que dichas extensiones prediales, comparadas con otras de la zona, puntualmente con las haciendas de los jesuitas, como las de Cato, Magdalena, El Torreón, Caimacagüin, con miles de cuadras ${ }^{56}$, eran considerablemente de menor tamaño ${ }^{57}$. Sin embargo, aportaron a la generación de un dinamismo económico que les permitió cumplir su labor evangelizadora en medio de la población hispano criolla y nativa.

El siguiente mapa muestra la ubicación territorial de las propiedades del Colegio de misiones de Chillán, localizados hacia el oriente de la ciudad durante el tránsito del siglo XVIII al XIX.

\section{Mapa №1}

Propiedades del Colegio de Misiones de Chillán, siglos XVIII-XIX

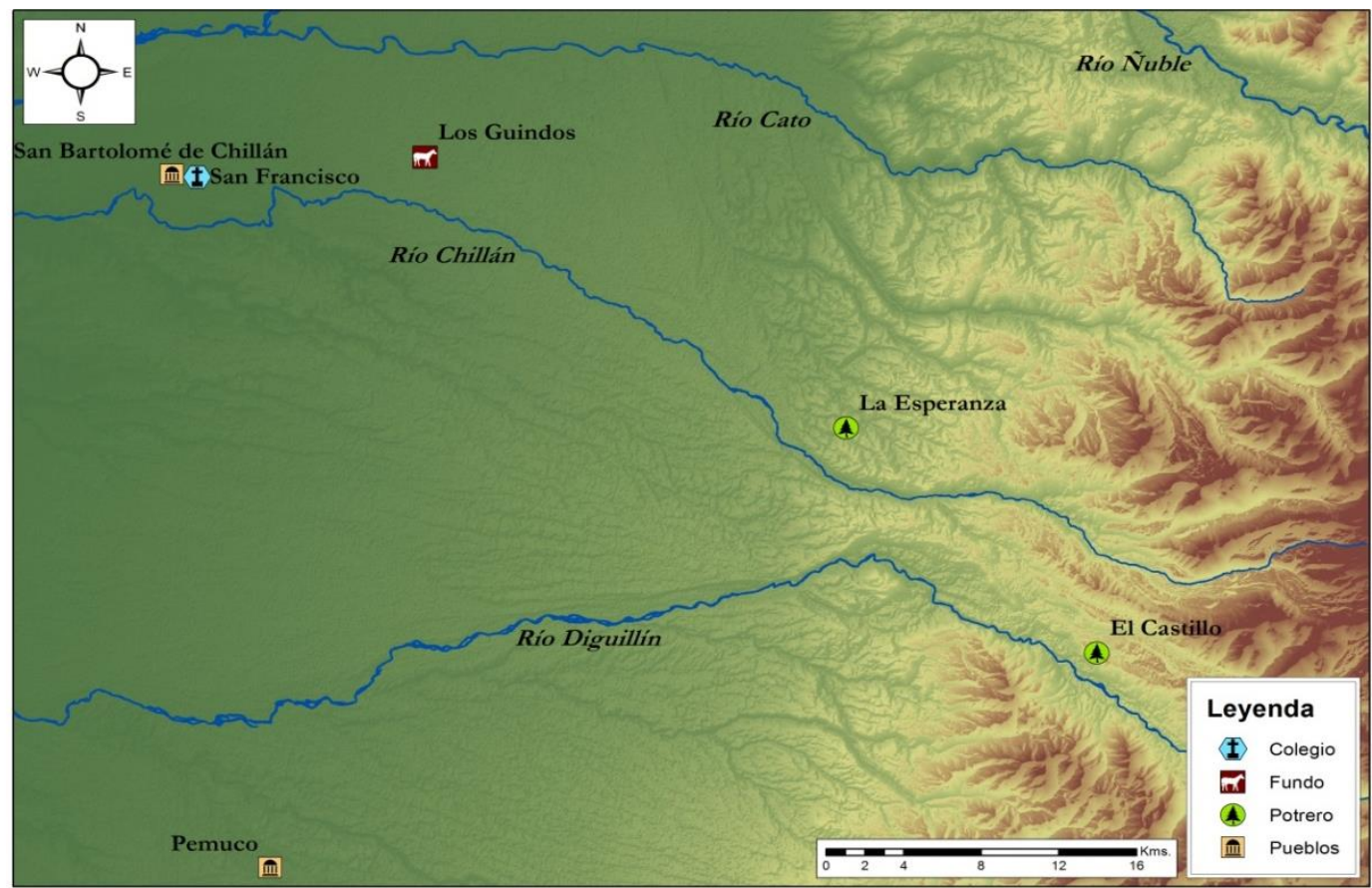

Fuente: Elaboración a partir de Secuestro de Bienes, 1824 de Rigoberto Iturriaga Carrasco, PAFSCh., $\mathrm{N}^{\circ}$ 40, 1995.

Respecto a los ingresos y gastos en plata que tenía el Colegio de Chillán desde 1764 a 1810, observamos una economía estable. Los ingresos totales para el período fueron

\footnotetext{
55 Dicha extensión se obtuvo del valor asignado a una cuadra y la información que proporciona el inventario del secuestro de bienes. Ver, ídem.

${ }^{56}$ Sánchez, Raúl, «La empresa económica jesuita en el obispado de Concepción: El caso de los colegios San Bartolomé de Chillán y Buena Esperanza», Revista UNIVERSUM, № 26, Vol. 2, Universidad de Talca, 2011(pp. 215-243).

57 Villalobos, Sergio y Rodríguez, Cristián. «El espacio rural Longaví-Ñuble, 1737». En Cuadernos de Historia, № 17, Universidad de Chile, Santiago, 1997 (pp. 105-144).
} 
de 82.643 pesos y tres reales, lo que equivale a un promedio anual de 1.796 pesos. Por su parte los gastos en alimentación, vestuario, salud, construcción, fletes, transporte y servicios varios, ascendían a la suma de 59.653 pesos un real, con un promedio de gasto anual de 1.296 pesos.

La relación ingresos gasto rara vez complicó al Colegio de misiones de Chillán. Los alcances, en su mayoría, fueron positivos. Por ejemplo, durante el período 1779 1810, sólo en dos ocasiones el alcance fue negativo: los años 1796 y 1807 1808. El déficit fue de 60 y 12 pesos, respectivamente. Todos los otros alcances, considerando un marco temporal de 46 años, fueron positivos. Dicha situación la podemos observar en la siguiente tabla:

Tabla $\mathrm{N}^{\circ}$ 1. Ingresos, gastos y alcances Colegio de Misiones de Chillán, 1764-1810

\begin{tabular}{|c|c|c|c|c|c|c|}
\hline \multirow{2}{*}{ Período } & \multicolumn{2}{|c|}{ Entradas } & \multicolumn{2}{c|}{ Gastos } & \multicolumn{2}{c|}{ Alcances } \\
\cline { 2 - 7 } & pesos & reales & pesos & reales & pesos & reales \\
\hline $1764-1765$ & 2947 & 1 & 2358 & 2 & 588 & 7 \\
\hline $1765-1768$ & 4112 & 5 & 3123 & - & 988 & - \\
\hline $1768-1769$ & 3118 & - & 1602 & 3 & 1.515 & 7 \\
\hline 1770 & 1978 & 2 & 975 & - & 1.003 & 2 \\
\hline 1771 & 2088 & 2 & 1057 & 5 & 1.030 & 5 \\
\hline $1771-1775$ & 12109 & 4 & 10537 & 1 & 1.572 & 3 \\
\hline $1775-1776$ & 2395 & 3 & 2122 & 1 & 273 & 2 \\
\hline $1776-1777$ & 1424 & 3 & 1058 & 3 & 366 & - \\
\hline $1779-1781$ & 2130 & 5 & 1094 & 7 & 1.035 & 6 \\
\hline $1780-1781$ & 2521 & 3 & 1126 & - & 1.395 & - \\
\hline $1779-1782$ & 6520 & 7 & 4105 & - & 2.417 & 7 \\
\hline $1782-1783$ & 2554 & - & 470 & 4 & 2.083 & 4 \\
\hline $1783-1784$ & 3981 & 1 & 2529 & 4 & 1.451 & 5 \\
\hline $1795-1796$ & 1089 & 6 & 1150 & 3 & -60 & 5 \\
\hline $1798-1801$ & 7559 & 7 & 6285 & 7 & 1.273 & 7 \\
\hline $1799-1800$ & 2911 & 6 & 1375 & 5 & 1.536 & 5 \\
\hline $1801-1803$ & 5030 & 3 & 3979 & - & 1.051 & 3 \\
\hline $1805-1807$ & 10510 & 2 & 8463 & 4 & 2.046 & 2 \\
\hline $1807-1808$ & 1432 & - & 1444 & - & -12 & - \\
\hline $1808-1810$ & 7659 & 7 & 6239 & - & 1.420 & 7 \\
\hline Total & 82.643 & 3 & 59.653 & 1 & 22.959 & 5 \\
\hline
\end{tabular}

Fuente: Elaboración a partir de Disposiciones Colegio Apostólico de Propaganda Fide de San Ildefonso de Chillán, 1764 1779 de Cristián Leal y Rigoberto Iturriaga, PAFSCh., № 107, 2013 y de Disposiciones Colegio Apostólico de Propaganda Fide de San Ildefonso de Chillán, 1779 1810 de Cristián Leal y Rigoberto Iturriaga, PAFSCh, $\mathrm{N}^{\circ} 109,2014$.

El Colegio de misiones tenía varios ítems de ingreso en plata, entre los cuales encontramos servicios religiosos (misas, entierros, sermones y capellanías), mortajas, pagos de las misiones, préstamos y deudas de los bienhechores, donaciones, ventas, 
conmutaciones y remanentes. El porcentaje de aporte de los citados ítems lo podemos observar en la siguiente gráfica.

\section{Gráfico $\mathrm{N}^{\circ}$ 1. Principales ingresos en plata (porcentajes) Colegio de Misiones de Chillán, 1764-1810}

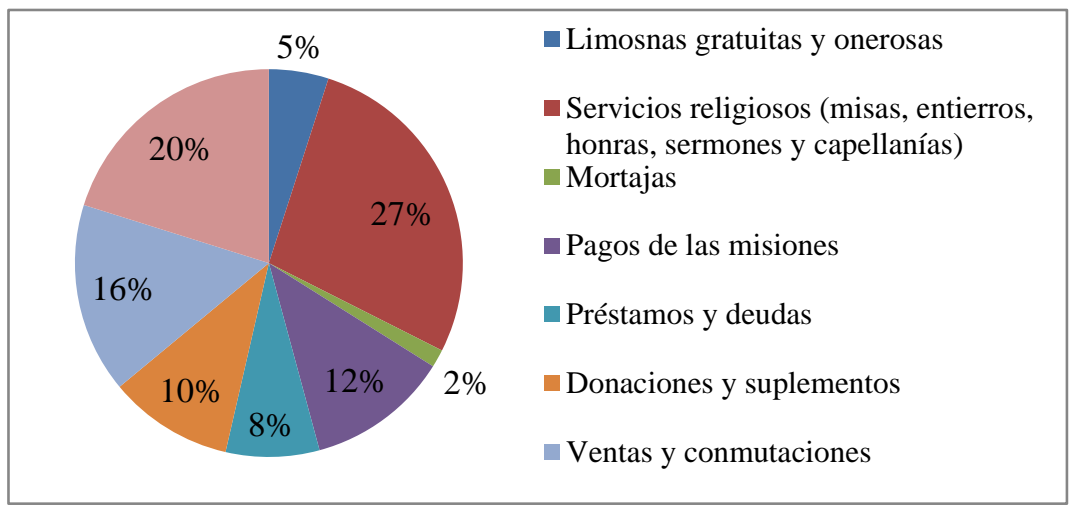

Fuente: Elaboración a partir de Disposiciones Colegio Apostólico de Propaganda Fide de San Ildefonso de Chillán, 1764 1779 de Cristián Leal y Rigoberto Iturriaga, PAFSCh., No 107, 2013 y de Disposiciones Colegio Apostólico de Propaganda Fide de San Ildefonso de Chillán, 1779 1810 de Cristián Leal y Rigoberto Iturriaga, PAFSCh, $\mathrm{N}^{\circ} 109,2014$.

El mayor porcentaje de ingreso lo aportaban los servicios religiosos que brindaba el Colegio a la comunidad. En ello, las misas, los entierros, honras, sermones y las capellanías, representan el $27 \%$ de los ingresos. Luego, con un $20 \%$ le siguen los remanentes de períodos anteriores, un $16 \%$ las ventas y conmutaciones, y un $12 \%$ los pagos por deudas de las misiones. Con porcentajes menores aparecen las donaciones, los ingresos por concepto de préstamos y deudas de particulares y las entradas por limosnas gratuitas y onerosas, con un $10 \%, 8 \%$ y $5 \%$, respectivamente.

El abastecimiento de los diversos productos que necesitaba el Colegio se hacía desde Concepción y Santiago. Los religiosos en cada viaje que realizaban a dichas ciudades, en ocasiones a cuenta del sínodo o de su propio peculio, aportaban con víveres, vestimentas y ornamentos sagrados, tanto para el Colegio como par a las misiones. En este sentido, importante fueron las gestiones o aportes de Tomás Torrico, Juan Matud, Domingo Lamas, Juan Calaf, Pedro Valcarce, Antonio Sorns, Miguel de Ascasubi, entre $\operatorname{otros}^{58}$.

No menor fueron los aportes en calidad de limosna que los obispos aportaban al Colegio. En este sentido, destacan para el período Manuel Alday y Aspé, obispo de Santiago, y Pedro Ángel de Espiñeira, obispo de Concepción. El primero, por ejemplo, en la cuenta de los años 1768 1769, da «200 pesos gratuitamente». El segundo, en varias oportunidades, muestra su preocupación e interés por los frailes franciscanos de Chillán, de quienes había sido su guardián. Así, en la cuenta de 1765 1768 otorga «128

\footnotetext{
${ }^{58}$ Leal, Cristián \& Iturriaga, Rigoberto, Disposiciones Colegio Apostólico de Propaganda Fide de San Ildefonso de Chillán. Segunda parte: 1779-1810, PAFSCh., № 109, 2014.
} 
pesos de limosna»; en la cuenta de los años 1768 a 1769, da «81 pesos y medio real gratuitamente»; en la cuenta de 1771 a 1775 , otorga «114 pesos para la obra de la construcción de la iglesia»59.

Otra vía muy importante fueron los ingresos en especies. El área territorial bajo «dominio» de los frailes para los efectos de las limosnas, estaba claramente demarcada: entre el río Maule por el norte y el río Itata por el sur, estándoles permitido también adentrarse en Yumbel ${ }^{60}$. Los limosneros recorrían un vasto y rico territorio, donde recogían no sólo animales, también trigo, lentejas, garbanzos y vino, que era de gran ayuda a la comunidad de religiosos. Fue tal la cantidad de limosnas en especies que se recogían, que se conmutaban por dinero u otros productos que escaseaban; situación que no sólo era una práctica del Colegio de Chillán, también se vivían en los conventos de la Provincia.

Por su parte, los ingresos en especie son abundantes en animales, cereales, legumbres y vino, lo que permitió a los frailes conmutar y pagar los múltiples servicios de terceros. Si pensamos en los trienios 1805 1807 y 1808 1810, la realidad fue la siguiente: Para el primero, y considerando sólo los animales vacunos (entre los que se consumieron, conmutaron y perdieron), la suma fue de 90961. De éstos se consumieron 397 en la matanza, 68 en la comunidad, 11 en la chacra y cordillera; 354 se conmutaron, 37 en peones y conchavos; muertos 29 y perdidos o robados $13^{62}$.

Los carneros sumaron 5.445, de ellos 3.886 se consumieron en la comunidad, 785 en la chacra, 345 se conmutaron, 429 muertos. Además, se consumieron 41 cerdos, 600 arrobas de charqui en comida de los peones y 580 se conmutaron. De trigo, se consumieron 1.300 en la comunidad, chacra y por el intercambio de leña. 1.689 en conmutación de especies diversas. Igualmente, se gastaron 800 arrobas de vino en la comunidad y 441 en pagar a maestros, peones, sayales y chacra. 24 arrobas de aguardiente se gastaron en la comunidad y en la chacra63.

En dicho período quedaron en la chacra Los Guindos 334 reses de vacunos, incluidos los bueyes y la engorda de los mismos. 2104 carneros, 146 caballos, 121 mulas, 18 chanchos, 32 aparejos y leña para más de un año. En el granero quedaban el año 1807, entre ladrillos y baldosas 300, 6.000 tejas, más de 500 toscas, 12 arrobas de cal; sobre 400 tablas y algunos umbrales ${ }^{64}$.

\footnotetext{
59 Leal, Cristián \& Iturriaga, Rigoberto, Disposiciones Colegio Apostólico de Propaganda Fide de San Ildefonso de Chillán. Primera parte: 1764-1779, PAFSCh., №107, 2013 , p.8.

${ }^{60}$ Actas del Definitorio, Constitución de 1712, volumen $N^{\circ} 2: 1693-1713$. Archivo Franciscano de Santiago de Chile.

${ }^{61}$ Leal, Cristián \& Iturriaga, Rigoberto, Disposiciones Colegio Apostólico de Propaganda Fide de San Ildefonso de Chillán. Segunda parte ..., op. cit., p. 6

62 Ídem.

63 Ídem.

64 Ídem.
} 
La forma de retribuir las entradas en especies por parte del Colegio, era a través de las misas y las mortajas. En siguiente cuadro muestra el costo de las donaciones durante el período 1808 1810 .

Tabla $\mathrm{N}^{\circ} 2$. Donaciones en alimentos y animales Costo en misas y mortajas, $1808-1810$

\begin{tabular}{|l|l|l|}
\hline \multicolumn{1}{|c|}{ Cantidad } & \multicolumn{1}{|c|}{ Alimentos/animales } & \multicolumn{1}{c|}{ Costo en misas y mortajas } \\
\hline 2.350 fanegas & Trigo & 157 misas y 20 mortajas \\
\hline 71 fanegas & Porotos & 23 misas y 5 mortajas \\
\hline 17 fanegas & Garbanzos & 4 misas y 2 mortajas \\
\hline 1.518 arrobas & Vino* & 445 misas y 19 mortajas \\
\hline 882 & Reses vacunas* & 257 misas y 28 mortajas \\
\hline 6.690 & Carneros & 141 misas y 30 mortajas \\
\hline *Incluye la recolección del período y la cantidad dejada por la guardianía anterior
\end{tabular}

Fuente: Construida a partir de Disposiciones Colegio Apostólico de Propaganda Fide de San Ildefonso de Chillán, 1779 1810 de Cristián Leal y Rigoberto Iturriaga, PAFSCh., No 109, 2014.

Hacia el año 1810, las existencias en el Colegio de Chillán en animales, alimentos, vino y aguardiente, materiales de construcción y por deudas a su favor, era no menor. Por ejemplo, el total de animales (vacunos, mulas, caballos, carneros y chanchos) era de 3.154. Además, debemos agregar la existencia de 100 fanegas de harina, 150 de trigo, 30 jamones, 80 salones, 200 arrobas de vino, 15 de aguardiente y un millar de baldosas, medio millar de ladrillos, 700 vellones de lana, por citar algunos ${ }^{65}$.

En el cuadro siguiente se puede observar la cantidad de ganado mayor y menor con que contaba el Colegio, como también los alimentos perecibles, vino y aguardiente y materiales de construcción que disponían.

Tabla $\mathrm{N}^{\circ} 3$. Existencia en animales, alimentos y otros Colegio de misiones de Chillán, 1810.

\begin{tabular}{|l|l|}
\hline \multicolumn{1}{|c|}{ Existencia } & \multicolumn{1}{c|}{ Cantidades } \\
\hline I.- Animales & 449 \\
\hline Vacunos & 138 \\
\hline Mulas & 140 \\
\hline Caballos & 2408 \\
\hline Carneros & 19 \\
\hline Chanchos & 3.154 \\
\hline Total & \multicolumn{2}{|l|}{} \\
\hline II. Otras existencias: Alimentos, vino/aguardiente y materiales de construcción \\
\hline 2.1.- Alimentos: & 100 fanegas \\
\hline Harina & 150 fanegas \\
\hline Trigo & 30 fanegas \\
\hline Garbanzos & 80 fanegas \\
\hline Jamones & (no específica) \\
\hline Salones & 18 arrobas \\
\hline Tocino para el año &
\end{tabular}

65 Ídem. 


\begin{tabular}{|l|l|}
\hline Pescado & 12 arrobas \\
\hline Grasa & (no específica) \\
\hline Sal & 25 piedras \\
\hline 2.2.- Vino y aguardiente & 200 arrobas \\
\hline Vino & 15 arrobas \\
\hline Aguardiente & \\
\hline 2.3.- Materiales de construcción y otros & 500 \\
\hline Ladrillos & 1.000 \\
\hline Baldosas & 700 \\
\hline Vellones de lana & 35 \\
\hline Odres & 60 \\
\hline Sacos & 50 \\
\hline Aparejos & Fuente: Construida a partir de Disposiciones Colegio Apostólico de Propaganda Fide de San Ildefonso de \\
Chillán, 1779 1810 de Cristián Leal y Rigoberto Iturriaga, PAFSCh., No 109, 2014. \\
\hline
\end{tabular}

A lo anterior, debemos sumar las deudas en dinero que tenían con el Colegio el Rey, hacendados, peones y las propias misiones. Hacia el año 1810, dicha deuda ascendía en su conjunto a la suma de 1.889 pesos y un par de reales. El siguiente cuadro da cuenta de ello:

Tabla $N^{\circ} 4$. Deudas en plata a favor

\section{Colegio de misiones de Chillán, 1810.}

\begin{tabular}{|c|c|}
\hline \multicolumn{2}{|c|}{ Deudas } \\
\hline \multicolumn{2}{|l|}{ 1.- Deudas en plata } \\
\hline El Rey por la fábrica del Colegio de Naturales & 1.117 pesos $63 / 4$ reales \\
\hline José Ponce & 55 pesos $2 \frac{1}{2}$ reales \\
\hline Bernardo Soto por sufragio de su hermana & 156 pesos \\
\hline Casimiro Cabrera & 26 pesos \\
\hline Manuel Zañartu & 50 pesos \\
\hline Total deuda & 91.429 pesos $51 / 2$ reales \\
\hline \multicolumn{2}{|l|}{ 2.- Deudas por efectos } \\
\hline Las sayaleras & 118 pesos \\
\hline Los peones & 104 pesos \\
\hline Total deuda por efectos & 222 pesos \\
\hline \multicolumn{2}{|l|}{ 3.- Deuda de las misiones } \\
\hline Misiones de Valdivia & 219 pesos 7 reales 3 cuartillos \\
\hline Misión de Arauco & 9 pesos $51 / 2$ reales \\
\hline Misión de Rucapén & 11 reales (1 peso, 3 reales) \\
\hline Misión de Santa Bárbara & 7 pesos \\
\hline Total deuda misiones & 237 pesos, 8 reales 3 cuartillos \\
\hline Total deuda en plata & 1.889 pesos, $5 \frac{1}{2}$ reales 3 cuartillos \\
\hline
\end{tabular}
Chillán, 1779 1810 de Cristián Leal y Rigoberto Iturriaga, PAFSCh., No 109, 2014.

\section{Relaciones económicas del Colegio de misiones de Chillán: Hacendados, misiones, instituciones y aborígenes}

El Colegio de misiones de Chillán no sólo se financió con el sínodo que brindaba la Corona, también debió establecer, como ya lo hemos dicho, relaciones con los misiones, los hacendados, instituciones y población aborigen. Con quien mantuvo una mayor 
actividad económica fue con las misiones, puntualmente con las de Arauco, Tucapel, Santa Barbara y Valdivia. Luego vienen los hacendados, hombres y mujeres, que se vincularon económicamente con el Colegio.

Sobre esto último, si bien los hombres son mayoría, las mujeres llegan a más de un tercio del total, lo cual nos debe hacer pensar en el rol que la historiografía tradicional ha entregado a la mujer ${ }^{66}$. Por lo visto no fue tan pasivo, más aún si encontramos que las encargadas de la administración del dinero de más de alguna misión franciscana era una mujer, en calidad de síndica, como lo fue Clara de Eslava y Lope en la misión de Valdivia ${ }^{67}$.

Otras mujeres que se vincularon económicamente con el Colegio fueron Manuela Isunsa, Josefa Friz, Nacinsa Gallegos y Angela Básquez, quiénes mantenían deudas con el Colegio no sólo por servicios religiosos, como misas, sermones y compra de mortajas, sino que también compraban al Colegio harina y cueros de vacuno68. Por ejemplo, en las cuentas de los años 1779 1780, Manuela Isunsa debía 56 pesos 2 reales, producto de la compra de harina ${ }^{69}$

Por su parte, los hombres que mayormente se vinculaban con el Colegio fueron: Pedro Bravo, Francisco Arias, Juan Arias y Fernando Troncoso, al mantener deudas con el Colegio por servicios religiosos (misas y honras), como también por la compra de mortajas, recibiendo el Colegio dinero, productos agrícolas (trigo fundamentalmente) y animales. ${ }^{70} \mathrm{El}$ siguiente gráfico da cuenta del predomino de las relaciones económicas de las misiones y los hombres, con una incipiente participación de las mujeres durante el período 1779 1810.

Gráfico N². Deudores del Colegio Hombres, mujeres y misiones 1779-1810.

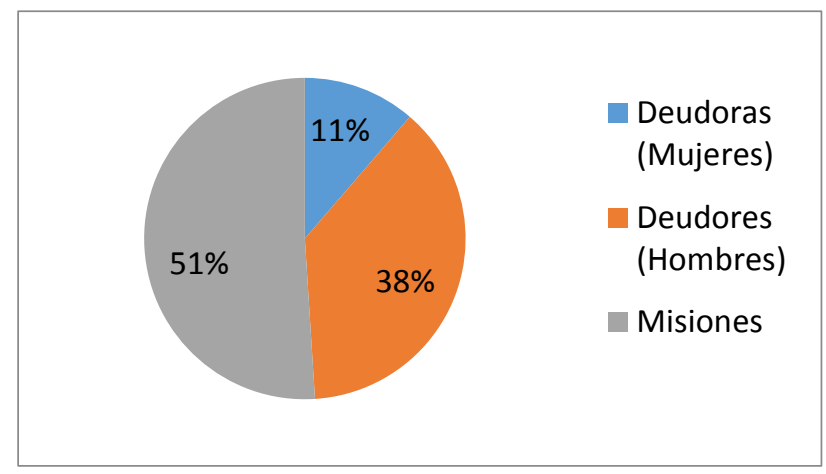

66 Jaime Peire, El Taller de los Espejos..., op. cit.

67 «Petición al Gobernador de la Síndica Clara de Eslava y Lope», 8 de abril de 1791, Valdivia. Archivo del Colegio de Propaganda Fide de San Ildefonso de Chillán, Asuntos Varios (1791-1792), vol.7, fjs. 11-12v.

${ }^{68}$ Leal, Cristián \& Iturriaga, Rigoberto, Disposiciones Colegio Apostólico de Propaganda Fide de San Ildefonso de Chillán. Segunda parte..., op. cit., pp. 48, 52, 60, 83, 109, 128.

${ }^{69}$ lbídem., p. 56

${ }^{7}$ Ibídem., pp. 59, 83, 109,110.111. 
Fuente: Elaboración a partir de Disposiciones Colegio Apostólico de Propaganda Fide de San Ildefonso de Chillán. Segunda parte: 1779 1810 de Cristián Leal y Rigoberto Iturriaga, $\mathrm{N}^{\circ} 109$, PAFSCh., Santiago de Chile, 2014.

Junto a lo anterior, es importante observar el área territorial de vinculación económica que tuvo el Colegio, que iba desde el curato de Parral por el norte a Valdivia por el sur, cubriendo una distancia de aproximadamente 510 kilómetros. En el mapa adjunto podemos observar localidades como La Estancia del Rey, ubicada en las inmediaciones de Rere, una zona de frontera con un territorio muy apto para los cultivos intensivos ${ }^{71}$. La Estancia del Rey fue «un lugar desde el cual se obtuvo gran parte de las provisiones para el ejército español» 72 . Se cultivaba «trigo y cereales», además de criar «cabras, ovejas y caballos» ${ }^{73}$, para los planes de conquista. De igual forma permitió, como en tiempos de los jesuitas ${ }^{74}$, enviar productos hacia las misiones. Por ejemplo, en las cuentas de los años 1779 1801, por efectos de conmutación, se envió vino a la misión de Arauco $^{75}$.

Entre los años 1782 y 1801, los comerciantes Victorino Oses y Juan de Arias, que vivían en la Estancia del Rey, mantuvieron relaciones económicas con el Colegio de misiones. Al primero se le enviaban arrobas de cocido; el segundo, mantenía una deuda de 52 pesos $^{76}$. De igual forma, y a raíz de la finalidad del Colegio, cual era ocuparse de los infieles, se generó naturalmente una mayor vinculación espiritual y económica con las misiones de Tucapel, Arauco, Santa Bárbara y Valdívia. Se enviaban hacia dichos lugares vestuario, alimentos, animales y vino. Por ejemplo, a la misión de Tucapel hacia el tránsito del siglo XVIII al XIX, se llevaban telas, principalmente sayal y sayalete, recibiendo el Colegio de la misión pescado: róbalo y blanquillo ${ }^{77}$. En dicho período, la misión de Arauco, junto con mantener una deuda en pesos, realizaba conmutaciones de sayal, sayalete y corderos por pescado de la costa de Arauco ${ }^{78}$.

Por su parte, la misión de Santa Bárbara y Valdivia, junto con mantener una deuda en pesos permanente con el Colegio a raíz del retraso del sínodo, eran abastecidas con géneros, frazadas y mantas ${ }^{79}$. Con el Hospicio de Santa Bárbara, puerta de entrada a tierras pehuenches y lugar de acogida, mantención y educación para los hijos de los caciques $^{80}$, mantenía el Colegio un permanente socorro en dinero a la espera del sínodo

\footnotetext{
${ }^{71}$ Umanzor Quintanilla, Bernarda y Silva Beltrán, Jaime, Rere, apuntes para su historia, Ediciones del Archivo Histórico de Concepción, Concepción, 2017.

72 Ibídem, p. 19.

73 Ibídem, p. 36.

74 Umanzor Quintanilla, Bernarda y Silva Beltrán, Jaime, op. cit.

${ }^{75}$ Leal, Cristián \& Iturriaga, Rigoberto, Disposiciones Colegio Apostólico de Propaganda Fide de San Ildefonso de Chillán. Segunda parte... op. cit., p. 22

${ }^{76}$ Ibídem, pp. 111, 203.

77 Ibídem, pp. 71,72, 87, 88, 121.

78 Ibídem, pp.13, 22, 260.

79 Ibídem, pp. 12, 123, 261.

80 Leal, Cristián, Quitral, Andrés, «Evangelización y occidentalización...», op. cit., pp. 150-156. 
por parte de la Corona Española, y en especies, tales como: sayal, sayalete, cera y madera para refaccionar las construcciones que por el paso del tiempo y los terremotos necesitaban mejoras. La madera era proporcionada por los fundos que el Colegio tenía en la Cordillera, donde había un aserradero.

Su radio de acción económica también involucró al Seminario de Naturales ${ }^{81}$. En su tercera etapa (1786 1811), fue administrado por los franciscanos del Colegio de misiones de Chillán. La finalidad del Seminario era «instruir al colegial para que, egresado del colegio, pasara a ser un agente cultural de cambio» ${ }^{82}$ dentro de sus comunidades. Bajo la administración de los franciscanos, los frailes seráficos cubrieron los gastos del instituto cuando el sínodo destinado para su financiamiento sufría retrasos prolongados. El Colegio, junto con disponer de tres religiosos al Seminario para la formación de los hijos de los caciques: Rector, Vice Rector y un Lego portero ${ }^{83}$, proveía a dicho instituto de alimentos como huevos, chocolate, frutas y cereales ${ }^{84}$.

De igual forma existió relación con territorios que en aquella época eran denominados curatos y partidos, como Parral, Ninhue, Puchacay y la Florida. Es común encontrar en las cuentas deudas de particulares referidas a servicios religiosos que no eran cancelados, como las misas, entierros y honras. Cuando éstos servicios eran pagados oportunamente, recibía el Colegio dinero, productos agrícolas, trigo y legumbre fundamentalmente, y animales ${ }^{85}$. Desde localidades como Buli y los baños de Perquilauquén también encontramos deudas de particulares por servicios religiosos y telas (sayal y sayalete), recibiendo a cambio dinero, trigo y legumbres ${ }^{86}$.

Finalmente, una relación económica importante fue la que se sostuvo el Colegio con los pehuenches ${ }^{87}$. Es conocida la actividad comercial que los españoles tuvieron con los pueblos ancestrales de la frontera ${ }^{88}$, pero poco conocida es aquella que los pueblos ancestrales sostuvieron con los religiosos seráficos. En las cuentas del Colegio correspondientes a los años 1768, 1769, aparece registrado el intercambio de sal por trigo: «10 anegas de sal que se conmutaron por trigo a los pehuenches». El año 1775,

\footnotetext{
${ }^{81}$ Ver en, Pereira, Karin, «Del Colegio al Seminario de Naturales: Los franciscanos y la educación indígena en Chile, 1786-1811», en Millar, René y Aránguiz, Horacio (editores), Los Franciscanos en Chile: Una historia de 450 años, Academia Chilena de la Historia, Santiago de Chile, 2005 (pp. 171-186); y en Pereira, Karin. El Real Colegio de Naturales, PAFSCh., N 73, Santiago de Chile, 2002.

82 Pereira, Karín, El Real Colegio de..., op. cit., p. 19

83 Ibídem., p. 137.

84 Leal, Cristián \& Iturriaga, Rigoberto, Disposiciones Colegio Apostólico de Propaganda Fide de San Ildefonso de Chillán. Segunda parte..., op. cit., pp. 177, 190, 212, 279.

85 Ibídem, pp. 83, 109, 110.

${ }^{86}$ Ibídem, pp. 109,110, 111.

87 Zavala, José, Los Mapuches del siglo XVIII. Dinámica interétnica y estrategias de resistencia, Universidad Bolivariana, Santiago, 2008.

${ }^{88}$ Ver, Pinto Rodríguez, Jorge e Inostroza Córdova, Iván, op. cit.; y León Solís, Leonardo, op. cit. 
el «cacique Francisco Lianca debe quatro mil y cinquenta adobes» ${ }^{89}$. Si bien no son datos concluyentes de una relación económica permanente, son indicios de una relación que como todas pasó por altos y bajos.

En el siguiente mapa podemos apreciar el área de vinculación económica que mantuvo el Colegio de Chillán con instituciones y localidades, llámese curatos o partidos, hacia fines del siglo XVIII y comienzos del XIX.

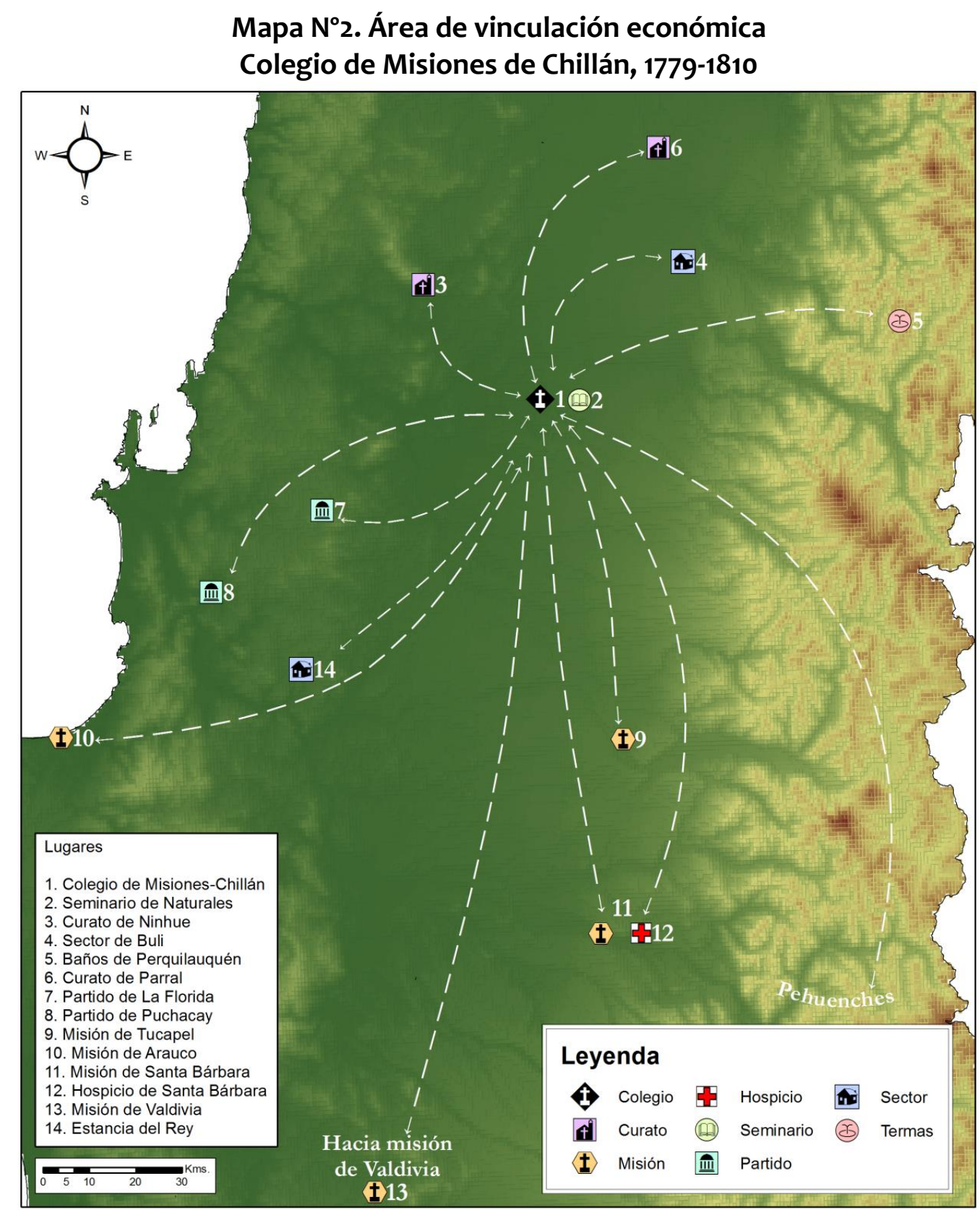

Fuente: Elaboración a partir de Disposiciones del Colegio de Propaganda Fide de San Ildefonso de Chillán, segunda parte 1779 1810 de Cristián Leal y Rigoberto Iturriaga, PAFSCh. №109, 2014.

${ }^{89}$ Leal, Cristián \& Iturriaga, Rigoberto, Disposiciones Colegio Apostólico de Propaganda Fide de San Ildefonso de Chillán. Primera parte... op. cit., pp. 32, 143. 


\section{Conclusiones}

La realidad económica de la frontera sur del Reino de Chile hacia fines del siglo XVIII, tuvo un dinamismo económico que no sólo es posible observar en Concepción, también en ciudades más pequeñas como Chillán. La existencia de mercados locales, nacionales e internacionales en productos agrícolas fue importante, siendo el trigo un producto que integró los diversos circuitos económicos, donde también estuvo presente la «región chillaneja».

Esta dinámica económica no sólo se manifestó entre la población hispano criolla, sino que también con los indígenas en tierras pehuenches y mapuches. La actividad económica contribuyó a generar un clima de paz y comunicación entre los grupos españoles, criollos e indígenas. En este contexto, los franciscanos del Colegio de misiones de Chillán también fueron el reflejo de dicha realidad, y al igual que la «macro» economía del Reino, esta «micro economía» de los frailes presentó cifras halagüeñas.

En cuanto a los ingresos en plata, no hubo alcances negativos, salvo raras excepciones, en un período de más de cuarenta años, como lo fue entre 1764 1810. El Colegio de misiones contó con propiedades y bienes semoventes (animales preferentemente) los que no sólo estuvieron al servicio de sus propias necesidades, sino que también del hospicio de Santa Bárbara, las misiones (Arauco, Rucapén, Tucapel y Valdivia), hacendados, Colegio de Naturales y los pehuenches.

El sínodo que recibían de la Corona española fue sólo una parte de sus ingresos, la mayoría era producto de las limosnas que recibía de los feligreses de manera gratuita y onerosa. Las propiedades, pequeñas en extensión, e incluso de escasas condiciones productivas, fueron de valiosa colaboración para la acción misionera en la población hispano criolla y los indígenas. Por ejemplo, en los fundos que existían hacia la cordillera, descritas como tierras yermas, aportaban la madera tan necesaria para las reparaciones de las construcciones en sus institutos y misiones. En dichos lugares existían aserraderos con operarios.

Hacia el año 1810, ad portas de la independencia, el Colegio de misiones de Chillán, logra establecer una red de comercio estable, y sobre todo «sana», construida durante los siglos coloniales, a partir de su labor evangelizadora en medio de la población hispano criolla e indígena. Esta micro economía si bien consideró lo establecido en los Estatutos respecto a la pobreza y al manejo de la pecunia, donde el síndico y el discretorio del Colegio debían velar por su cumplimiento, observamos que estos no 
siempre se cumplían del todo. La racionalidad y la utilidad en la administración de los recursos también estuvieron presentes.

\section{Bibliografía:}

\section{Fuentes Primarias}

\subsection{Fuentes Manuscritas}

- Estatutos Generales de Barcelona para la familia cismontana de la Regular observancia de N.P.S. Francisco, Madrid, 1746.

- Actas del Definitorio, Constitución de 1712, volumen $\mathrm{N}^{\circ}$ 2: 1693 1713. Archivo Franciscano de Santiago de Chile.

- «Petición al Gobernador de la Síndica Clara de Eslava y Lope», 8 de abril de 1791, Valdivia. Archivo del Colegio de Propaganda Fide de San Ildefonso de Chillán, Asuntos Varios (1791 1792), vol.7, fjs. 11 12v.

\subsection{Fuentes Impresas}

- «Informe del Presidente Amat y Junient a Carlos III, 1760» en Domingo Amunátegui Solar, Hijos Ilustres de Chillán, Prensa de la Universidad de Chile, Santiago, 1937.

- Ascasubi, Miguel, Informe cronológico de las misiones del Reino de Chile hasta 1789, en Publicaciones del Archivo Franciscano, Santiago (en adelante PAFSCh.), $\mathrm{N}^{\circ} 49,1997$.

- Gutiérrez, Bernardino, Catalogo de las casas de la Provincia Franciscana de la Santísima Trinidad (1553 1890), PAFSCh., No 33, 1994.

- Etcheverry, Paulinna, Las Prefecturas Franciscanas de Misiones en Chile, PAFSCh., $\mathrm{N}^{\circ} 71,2002$.

- Iturriaga, Rigoberto, Secuestro de Bienes, 1824, PAFSCh., № 40, 1995.

- Lagos, Roberto, Historia de las misiones del Colegio de Chillán, Ediciones Herederos Juan Gil, Barcelona, España, 1908.

- Leal, Cristián \& Iturriaga, Rigoberto, Disposiciones Colegio Apostólico de Propaganda Fide de San Ildefonso de Chillán. Primera parte: 1764 1779, PAFSCh., No107, 2013.

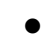

Disposiciones Colegio Apostólico de Propaganda Fide de San Ildefonso de Chillán. Segunda parte: 1779 1810, PAFSCh., No 109, 2014.

- Olivares, Luis, Provincia Franciscana de Chile, Universidad Católica, Santiago, 1961

\section{Fuentes Secundarias}

- Burns, Kathryn. Colonial Habits: Convents and the Spiritual Economy of Cuzco, Peru. Duke University Press, EEUU, 1991.

- Cartes Montory, Armando (Editor). El regreso del Prócer Don Juan Martínez de Rozas en la ciudad de Concepción, Ediciones del Archivo Histórico de Concepción, Concepción, 2017.

- Casanova Guarda, Holdenis, Las rebeliones araucanas del siglo XVIII, Ediciones Universidad de La Frontera, Serie Quinto Centenario, Temuco, 1987. 
Diablos, Brujos y Espíritus Maléficos. Chillán, un proceso judicial del siglo XVIII, Ediciones Universidad de La Frontera, Temuco, 1994.

- Cavieres FigueroA, Eduardo, Servir al soberano sin detrimento del vasallo. El comercio hispano colonial y el sector mercantil de Santiago de Chile en el siglo XVIII, Valparaíso, 2003.

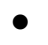

Sobre la Independencia en Chile. El fin del Antiguo Régimen y los origenes de la representación moderna, Ediciones Universitarias de Valparaíso, Valparaíso, 2012.

- Di Stefano, Roberto, El púlpito y la plaza. Clero, sociedad y política de la monarquía católica a la república rosista, Siglo XXI editores, Buenos Aires, 2004. , Historia de la Iglesia Argentina, Editorial Sudamericana,

Buenos Aires, 2009.

- Guarda, Gabriel, La Edad Media de Chile. Historia de la Iglesia desde la fundación de Santiago a la incorporación de Chiloé, 1541 1826, Colección Arte y Cultura, Ediciones UC, Santiago, 2016.

- LAVRin, Asunción, «Cofradías novohispanas: economías material y espiritual», en Cofradias, capellanías y obras pías en la América colonial, María Martínez, Gisela y von Wobeser, Juan Muñoz (coordinadores), Serie Historia Novohispana, 61, Universidad Nacional Autónoma de México, México, 1998 (pp. 49 64).

- LEAL, Cristián, «La realidad económica del Colegio de Propaganda Fide de Chillán en el periodo tardo colonial», en Cáceres, Juan, Tobar, Leopoldo y Leal, Cristián (editores), Lecturas y (RE) Lecturas en Historia Colonial II, Andros impresores, Santiago, 2013 (pp. 215 237).

- LEal, Cristián; QuiTral, Andrés, «Evangelización y occidentalización en la frontera sur del Reino de Chile. Los Franciscanos del Colegio de Misiones de Chillán, s. XVIII», en Revista Historia y MEMORIA, No 15, Julio Diciembre, Tunja, 2017 (pp.139 168).

- LEón Solís, Leonardo. Maloqueros y conchavadores en Araucanía y las pampas, 1700 1800, Universidad de la Frontera, Temuco, 1990.

- Mayo, Carlos; Peire, Jaime, «Iglesia y crédito colonial: La política crediticia de los conventos de Buenos Aires (1767 1810)», Revista de Historia de América, № 12 , 1991 (pp.147 157).

- Millar, René; Duhart, Carmen, «La vida en los claustros: Monjas y frailes, disciplinas y devociones», en Historia de la vida privada en Chile. El Chile tradicional de la conquista a 1840, Editorial Taurus, Santiago, 2007 (pp. 125 159).

- Palacios, Alfredo, Fuentes para la historia sísmica de Chile (1570 1906). Fuentes para la Historia de la República, volumen XLI. Dirección de Bibliotecas, Archivos y Museos, Santiago, 2016.

- PeIRE, Jaime, El Taller de los Espejos. Iglesia e imaginarios 1767 1815, Editorial Claridad, Buenos Aires, 2000.

- Pereira, Karin, «Del Colegio al Seminario de Naturales: Los franciscanos y la educación indígena en Chile, 1786 1811», en Millar, René y Aránguiz, Horacio (editores), Los Franciscanos en Chile: Una historia de 450 años, Academia Chilena de la Historia, Santiago, 2005 (pp. 171 186).

- $\quad$ El Real Colegio de Naturales, PAFSCh, $\mathrm{N}^{\circ}$ 73, 2002.

- Pinto Rodríguez, Jorge e Inostroza Córdova, Iván, Expansión capitalista y economía mapuche: 1680 1930, Ediciones Universidad de La Frontera, Temuco, 2014. 
- Revuelta, Manuel, La exclaustración (1833 1840), Editorial Católica, Madrid, 1976.

- SÁNCHEZ, Raúl, «La empresa económica jesuita en el obispado de Concepción: El caso de los colegios San Bartolomé de Chillán y Buena Esperanza», Revista UNIVERSUM, No 26, Vol. 2, Universidad de Talca, 2011 (pp. 215 243).

- Umanzor Quintanilla, Bernarda y Silva Beltrán, Jaime, Rere, apuntes para su historia, Ediciones del Archivo Histórico de Concepción, Concepción, 2017.

- Valenzuela, Jaime, «Los Franciscanos de Chillán y la Independencia: Avatares de una comunidad monarquista», Revista HISTORIA, $\mathrm{N}^{\circ}$ 38, Vol. I, enero junio, Santiago, 2005 (pp. 113 158).

- VAn Deusen, Nancy. «Instituciones religiosas en el mundo colonial americano», en Manifestaciones religiosas en el mundo colonial americano, de Garcia, C. y Ramos, M. (coord.), Universidad Iberoamericana, México, 1994 (pp. 65 86).

- Villalobos Rivera, Sergio. Los pehuenches en la vida fronteriza, Ediciones Universidad Católica de Chile, Santiago, 1989.

- Villalobos, Sergio y Rodríguez, Cristián. «El espacio rural Longaví Ñuble, 1737». En Cuadernos de Historia, $N^{\circ}$ 17, Universidad de Chile, Santiago, 1997 (pp. 105 144)

- ViÑuela, Rebeca, «Los Franciscanos del Colegio de Propaganda FIDE de San Ildefonso de Chillán como mediadores políticos en la Frontera Araucana del siglo XVIII», en América Cruces de Miradas, de Cañedo y Argüelles, Teresa (coordinadores), 2 volúmenes, Universidad de Alcalá, España, 2015 (pp. 577 602).

- Von Wobeser, Gisela, El Crédito Eclesiástico en la Nueva España, siglo XVIII, Universidad Autónoma de México, México, 1994.

- $\longrightarrow$ Vida eterna y preocupaciones terrenales. Las capellanías de misas en la Nueva España, 1700 1821, UNAM, México, 1999.

- ․ Dominación Colonial. La consolidación de vales reales, 1804 1812, Instituto de Investigación Histórica, Universidad Nacional Autónoma de México D.F, México, 2003.

- Zavala, José, Los Mapuches del siglo XVIII. Dinámica interétnica y estrategias de resistencia, Universidad Bolivariana, Santiago, 2008. 